\title{
Physical habitat assessment in the Tajuña river (Spain) by means of the MesoHABSIM approach
}

\author{
Javier Gortázar ${ }^{1,2, *}$, Piotr Parasiewicz ${ }^{3}$, Carlos Alonso-González² and Diego García de Jalón² \\ ${ }^{1}$ Ecohidráulica S.L. C/ Rodríguez San Pedro 13. 28015 Madrid. www.ecohidraulica.com. \\ ${ }^{2}$ Grupo de Investigación Hidrobiología. Departamento de Ingeniería Forestal. Escuela Técnica Superior de \\ Ingenieros de Montes. Universidad Politécnica de Madrid. Av. Ramiro de Maeztu s/n. 28040 Madrid. \\ ${ }^{3}$ Rushing Rivers Institute. 50 Two Ponds Road. Belchertown, MA. 01007 USA. www.RushingRivers.org. \\ * Corresponding author: jgortazar@ecohidraulica.com
}

Received: $22 / 6 / 2010$

Accepted: 22/3/2011

\begin{abstract}
Physical habitat assessment in the Tajuña river (Spain) by means of the MesoHABSIM approach

Physical habitat was assessed in the Tajuña river (Tagus basin, Spain) by means of the MesoHABSIM approach. Long reaches of the Tajuña river are altered by agricultural use of the riverside. The main impacts are river rectification (straightening), channel entrenchment and incision, and degradation of riparian vegetation, along with important flow depletion and regulation. To our knowledge, this is the first application in Spain of MesoHABSIM, which is a physical habitat model based on the identification of habitat attributes - depth, water velocity, substrate, types of hydromorphologic units (HMU), and types of cover - on the mesohabitat scale.

The river was stratified into 16 segments with similar habitat characteristics. Mesohabitats were mapped in one representative site (1-2 km long) within each segment to provide a hydromorphologic model of the river. Biological models were developed for fry, juvenile, and adult brown trout. To do this, preliminary models were generated based on literature about trout habitat requirements, and then they were calibrated with electrofishing data. These models were applied to the hydromorphologic model of the river to quantify the available habitat for brown trout in the current conditions. Finally, restoration action was designed to decrease channel entrenchment, increase river sinuosity, and recover its riparian vegetation. The physical changes after restoration were estimated by expert opinion, and the quantification of the available habitat was done with MesoHABSIM at each site. These results can be used to select the segments that are the best candidates for restoration.
\end{abstract}

Key words: MesoHABSIM, mesohabitat, hydromorphologic unit (HMU), physical habitat, restoration, brown trout.

\section{RESUMEN}

\section{Evaluación del hábitat físico en el río Tajuña (España) mediante la metodología MesoHABSIM}

Se ha evaluado el hábitat físico en el río Tajuña (cuenca del Tajo, España) mediante la metodología MesoHABSIM. Una parte importante del río Tajuña está alterada por los usos agrícolas de las riberas. Los principales impactos son la rectificación, el encajonamiento e incisión del cauce, y la degradación de la vegetación riparia, junto con una importante extracción y regulación del caudal.

Hasta donde conocemos, ésta es la primera aplicación de MesoHABSIM en España. Se trata de un modelo de hábitat físico, basado en la identificación de los atributos del hábitat -profundidad, velocidad del agua, sustrato, tipo de unidad hidromorfológica (HMU) y tipo de cobertura o refugio- en la escala del mesohábitat.

Se estratificó el río en 16 segmentos con características similares de hábitat. En cada segmento se muestrearon los mesohábitats en un tramo representativo de 1-2 km de largo, construyendo así un modelo hidromorfológico del río. Se generaron modelos biológicos para alevines, juveniles y adultos de trucha común. Para ello, se construyeron unos modelos preliminares a partir de bibliografía acerca de los requerimientos de hábitat de la trucha, y después se calibraron con datos obtenidos mediante pesca eléctrica. Estos modelos fueron aplicados al modelo hidromorfológico para cuantificar el hábitat disponible para la trucha común en las condiciones actuales. Finalmente se diseñó una acción de restauración con el objetivo de disminuir el encajonamiento del cauce, aumentar su sinuosidad y recuperar su vegetación riparia. Los cambios tras la 
restauración se estimaron por opinión de experto, y la evaluación del hábitat resultante se realizó mediante MesoHABSIM. Estos resultados pueden emplearse para elegir los segmentos más apropiados para realizar la restauración propuesta.

Palabras clave: MesoHABSIM, mesohábitat, unidad hidromorfologica (HMU), hábitat físico, restauración, trucha común.

\section{INTRODUCTION}

There are several tools for the assessment of physical habitat in rivers on a microhabitat scale, such as PHABSIM (Bovee, 1982), RHYHABSIM (Jowett, 1989), and EVHA (Ginot, 1995). Habitat studies in a river channel can be applied on different scales of analysis, such as the microhabitat or mesohabitat scales. For instance, microhabitat scale models within the IFIM framework have been broadly used in Spain, primarily for the establishment of ecological flow regimes.

The approach used in this work, MesoHABSIM, involves the use of the mesohabitat scale in data acquisition and analysis, and this defines its characteristics and applications. MesoHABSIM is an approach for modelling physical habitat in rivers. It allows a user to quantify the available habitat for selected fauna under specific environmental circumstances, and it can be used to simulate diverse scenarios, such as river alterations or restoration measures (Parasiewicz et al., 2009). The rationale of MesoHABSIM is the recognition that fauna reacts to the environment on different scales related to the size and mobility of the species as well as to the time of use. Therefore, the effort is focused on the habitat characterisation on the meso-scale level. Meso-scale units can be defined as areas where an animal can be observed for a significant portion of its diurnal routine, and it roughly corresponds with the concept of "functional habitat" (Kemp et al., 1999). Observation on the meso-scale can be expected to provide meaningful clues about an animal's selection of living conditions (Hardy \& Addley, 2001).

This paper describes the first application in Spain of the MesoHABSIM approach. It was an eminently practical application with the following objectives: to evaluate the current habitat availability for the brown trout in the Tajuña river and to quantify the habitat improvement that would be obtained if a specific restoration action was implemented.

\section{METHODS}

The work presented here applies the underlying concepts of the MesoHABSIM approach and its fundamental methods, but it is a simplification of the standard MesoHABSIM process, primarily due to budget constraints. The main modifications from the usual process are the following: (1) although MesoHABSIM usually considers habitat use within a range of flow values, in this work, the habitat was analysed under a single flow magnitude; (2) our study focuses on a single species, the brown trout (Salmo trutta L.), while MesoHABSIM permits consideration of the entire fish community; and (3) the biological models that define the kind of habitat used by the fish are normally generated by sampling fish with "electrogrids" (Bain et al., 1985) in several mesohabitats and processing data with logistic regression analysis, but in this work, we have built literature-based models and calibrated them with the available electrofishing data.

\section{Study site}

The Tajuña river is located in the province of Guadalajara, Spain, and it flows westward into the Jarama river, which belongs to the Tagus basin. The study site was a $116 \mathrm{~km}$ long segment of the Tajuña river between its source and the confluence with its tributary, the San Andrés river. Brown trout (Salmo trutta L.) is the most abundant species inhabiting the study site. Other autochthonous species in the fish community are barbel (Barbus bocagei Steindachner), Iberian nase 
(Pseudochondrostoma polylepis Steindachner), Iberian chub (Squalius pyrenaicus Günther), "bermejuela" (Achondrostoma arcasii Steindachner), "calandino" (Iberocypris alburnoides Steindachner) and Iberian loach (Cobitis paludica de Buen). The exotic species present are gudgeon (Gobio lozanoi Doadrio \& Madeira) and rainbow trout (Oncorhynchus mykiss Walbaum).

The most obvious alterations of the Tajuña river are caused by agriculture on the margins of the river course. This land use is responsible for several stressors that configure the current geomorphology of the river (Palmer et al., 2010). The main alterations are the rectification of several reaches that reduce sinuosity, the incision and entrenchment of the riverbed, which makes the channel deep and homogeneous, and the degradation of the riparian vegetation, along with an important flow depletion and regulation to irrigate the adjacent crops.

Segments 2, 7, 8 and 12 (see below) do not suffer from these alterations, and their physical habitat is little altered or unaltered because they flow through narrow valleys with poor accessibility where it has not been possible to develop agricultural fields. These segments show a diversity of HMU types, with notable numbers of riffles and rapids. Cascades, backwaters and side arms are also present, thus providing a diversity of microhabitats. Therefore, restoration was not a priority in these segments.

\section{MesoHABSIM application}

A detailed description of the MesoHABSIM approach is provided in Parasiewicz (2007) and Parasiewicz et al. (2009). It follows the typical structure of habitat models described by Parasiewicz \& Dunbar (2001) and is an aggregation of three models: (1) a hydromorphologic model that describes the spatial mosaic of fishrelevant physical features, (2) a biological model describing habitat use by animals, and (3) a habitat model quantifying the amount of usable habitat.

The study area was stratified in 16 segments (Table 1) based on a reconnaissance survey of the whole river and on the interpretation of aerial photographs and focusing on alterations and land
Table 1. Characterisation of the 16 segments in the Tajuña river: Length, mean altitude and gradient. Caracterización de los 16 segmentos definidos en el río Tajuña: longitud, altitud media y pendiente.

\begin{tabular}{cccc}
\hline Segment & $\begin{array}{c}\text { Length } \\
(\mathbf{k m})\end{array}$ & $\begin{array}{c}\text { Altitude } \\
(\mathbf{m} \text { a.s.l.) }\end{array}$ & $\begin{array}{c}\text { Gradient } \\
(\boldsymbol{\%})\end{array}$ \\
\hline 1 & 4.77 & 1164 & 0.34 \\
2 & 6.36 & 1134 & 0.71 \\
3 & 8.56 & 1094 & 0.41 \\
4 & 2.19 & 1073 & 0.27 \\
5 & 9.86 & 1046 & 0.20 \\
6 & 5.62 & 1030 & 0.21 \\
7 & 12.01 & 1001 & 0.38 \\
8 & 4.46 & 897 & 0.47 \\
9 & 11.85 & 887 & 0.16 \\
10 & 5.55 & 863 & 0.52 \\
11 & 3.79 & 839 & 0.47 \\
12 & 2.75 & 824 & 0.47 \\
13 & 9.03 & 798 & 0.42 \\
14 & 4.08 & 775 & 0.20 \\
15 & 9.00 & 752 & 0.42 \\
16 & 13.60 & 718 & 0.23 \\
\hline
\end{tabular}

use changes along the river. Within each segment, one representative site (1-2 km long) was chosen for the mesohabitat survey, accounting for $16.7 \%$ of the total study area length.

In each site, a mesohabitat survey was performed in June and July, 2009. Every hydromorphologic unit (HMU) within the site was identified, and its outlines were drawn as georeferenced polygons on a Pocket PC, using GIS software and aerial photographs. The physical attributes were estimated for each HMU, and the data were entered into a GIS table associated with the corresponding polygon. The physical attributes considered were the HMU type, the cover types (using three categories: absent, present and abundant), and the proportions of depth, mean column velocity and substrate classes within the unit (for a description of the physical attributes, see Parasiewicz, 2007). Depth, mean column velocity and estimated substrate were measured in seven random locations within each HMU. Measurements for depth and water velocity were taken with a Dipping Bar (Jens, 1968). Substrate definitions were based on the substrate classification system according to the Austrian Standard ÖNORM 6232 (1995). 
During the mesohabitat surveys, the flow related to the catchment area in each site was $0.0011 \mathrm{~m}^{3}$ $\mathrm{s}^{-1} \mathrm{~km}^{-2}\left(0.1 \mathrm{ft}^{3} \mathrm{~s}^{-1} \mathrm{mile}^{-2}\right)$, similar to the usual flow during summer. Therefore, our results refer solely to moderate flow conditions and cannot be applied to spates or extreme droughts.

We generated the biological models by considering the habitat use of three developmental stages of brown trout: fry $(0+$ age class, fork length $<102.5 \mathrm{~mm})$, juvenile $(1+$ age class, $102.5 \mathrm{~mm}<\mathrm{FL}<182.5 \mathrm{~mm}$ ) and adult (older fish, FL $>182.5 \mathrm{~mm}$ ). Preliminary biological models were generated based on the literature and were calibrated with electrofishing data obtained in the Tajuña river. To specify the affinity of fish presence with depth, water velocity and substrate, we used suitability curves developed by Bovee (1978, category I curves as defined by Armour et al., 1984, i.e., based on literature sources or professional opinion), Raleigh et al. (1986, category I) and Heggenes (1990, category III or preference curves). To define the brown trout preferences for HMU and cover types, the review on brown trout habitat requirements by Armstrong et al. (2003) was consulted. When the literature provided different values for distinct parts of the year or flow magnitudes, we used those that referred to either summer or moderate flow conditions because our study focused on habitat availability with moderate flow, which we assume occurs during the summer and, some years, even during a part of the spring and fall. The preliminary model consisted of certain HMU types, intervals of depth and velocity, and features of cover and substrate that are associated with a "suitable" habitat (if 3 of them occur) or with an "optimal" habitat (if 5 of them occur); the model is not a curve or a continuous variable but intervals or features to be considered in the habitat evaluation.

Once the preliminary biological models were generated, they were calibrated with quantitative electrofishing data to maximise the model's ability to explain the observed trout densities. Electrofishing data were obtained during July 2009, in a period of flow similar to that of the mesohabitat survey. Fish were sampled with pulsed direct current in twelve river reaches, each $c .100 \mathrm{~m}$ long, located within the mapped sites. Trout den- sity was estimated with the three-pass removal method, following Carle \& Strub (1978). To calibrate the model for each developmental stage, we performed a linear regression analysis in the sites with available electrofishing data, relating the following two variables: brown trout density (individuals $\mathrm{m}^{-2}$ ) and proportion of effective habitat within the electrofished area related to the mapped surface. Effective habitat is an aggregation of suitable and optimal habitats with different weights to assure a high contribution of the "optimal" habitat: Effective habitat = Suitable habitat + 1.5 Optimal habitat. Model calibration consisted of an iterative process: for each iteration, one class of one variable (a single depth, a velocity or substrate class, or a single HMU or cover type) was included in the model or excluded from it, and the linear regression analysis between trout density and effective habitat was calculated again. After each change, if the regression analysis reflected a better adjustment, the change was included in the model. Otherwise, the change was rejected.

The combination of the existing habitat features (hydromorphologic model) and the habitat used by the fish (biological model) provided the habitat model, which classifies the suitability of each HMU into three categories: not suitable, suitable and optimal (see Parasiewicz 2007 for more detail).

\section{Physical habitat restoration}

To propose specific restoration measures to improve habitat availability, it is necessary to identify which habitat attributes should be increased or decreased. To make these ecologically based decisions, it was necessary to identify the current habitat deficits for the three life stages of brown trout and to determine at which life stage habitat is more limited.

For the identification of habitat deficits, the current physical habitat characteristics (Table 2) were compared with the needs of brown trout as detailed in the biological models. Habitat deficits were identified by visual inspection of Table 2 .

To identify the life stage with the most limited habitat, we compared the current proportions of available habitat for each developmen- 
Table 2. Physical habitat characteristics in the current summer conditions. For HMU and cover types, the proportion of HMUs with the attribute is given (cover types are not mutually exclusive). For depth, velocity and substrate, the proportion of each class in the study area is given. Superscripts indicate suitable attributes for adult (A), juvenile (J) or fry (F), based on the biological models. Características del hábitat físico actual en verano. Para el tipo de HMU y refugio, se muestra la proporción de HMUs con el atributo (los tipos de refugio no se excluyen mutuamente). Para la profundidad, velocidad y sustrato, se muestra la proporción de cada clase en el área de estudio. Los superíndices indican los atributos adecuados para el adulto (A), juvenil (J) o alevín $(F)$, según los modelos biológicos.

\begin{tabular}{lc}
\hline Depth (cm) & Prop. \\
\hline$<25$ & 0.29 \\
$25-50^{\mathrm{J}, \mathrm{F}}$ & 0.30 \\
$50-75^{\mathrm{A}, \mathrm{J}, \mathrm{F}}$ & 0.17 \\
$75-100^{\mathrm{A}, \mathrm{J}}$ & 0.08 \\
$100-125^{\mathrm{A}}$ & 0.05 \\
$>125^{\mathrm{A}}$ & 0.10 \\
\hline
\end{tabular}

\begin{tabular}{lc}
\hline Velocity $\left(\mathbf{c m ~ s}^{\mathbf{- 1}}\right)$ & Prop. \\
\hline$<15^{\mathrm{A}, \mathrm{J}}$ & 0.37 \\
$15-30^{\mathrm{A}, \mathrm{J}, \mathrm{F}}$ & 0.24 \\
$30-45^{\mathrm{A}, \mathrm{J}, \mathrm{F}}$ & 0.19 \\
$45-60^{\mathrm{J}, \mathrm{F}}$ & 0.10 \\
$60-75$ & 0.05 \\
$75-90$ & 0.03 \\
$90-105$ & 0.01 \\
$>105$ & 0.02 \\
\hline
\end{tabular}

\begin{tabular}{lc}
\hline HMU type & Prop. \\
\hline Rapids $^{\mathrm{A}, \mathrm{J}, \mathrm{F}}$ & 0.05 \\
Riffle $^{\mathrm{A}, \mathrm{J}, \mathrm{F}}$ & 0.08 \\
Pool $^{\mathrm{A}, \mathrm{J}}$ & 0.18 \\
Side arm $^{\mathrm{F}}$ & 0.00 \\
Backwater $^{\mathrm{F}}$ & 0.00 \\
Cascade & 0.00 \\
Ruffle & 0.18 \\
Run & 0.20 \\
Glide & 0.29 \\
Plungepool & 0.00 \\
\hline
\end{tabular}

\begin{tabular}{lc}
\hline Cover type & Prop. \\
\hline Boulders $^{\mathrm{A}, \mathrm{F}}$ & 0.33 \\
Undercut $^{\mathrm{A}, \mathrm{J}, \mathrm{F}}$ & 0.33 \\
Shallow margin $^{\mathrm{F}}$ & 0.41 \\
Submerged Veg. $^{\mathrm{A}}$ & 0.50 \\
RipRap & 0.04 \\
Overhanging Veg. & 0.71 \\
Canopy Cover & 0.76 \\
Woody Debris & 0.40 \\
Low Gradient & 0.89 \\
\hline
\end{tabular}

\begin{tabular}{lr}
\hline Substrate & Prop. \\
\hline Pelal $^{\mathrm{A}}$ & 0.27 \\
Akal $^{\mathrm{F}}$ & 0.04 \\
MicroLithal $^{\mathrm{F}}$ & 0.20 \\
MesoLithal $^{\mathrm{A}, \mathrm{J}}$ & 0.14 \\
MacroLithal $^{\mathrm{F}}$ & 0.06 \\
MegaLithal $^{\mathrm{A}, \mathrm{J}, \mathrm{F}}$ & 0.06 \\
Phytal $_{\text {Psammal }}$ & 0.13 \\
Xylal & 0.08 \\
Sapropel & 0.01 \\
Debris & 0.01 \\
Detritus & 0.00 \\
Gigalithal & 0.00 \\
\hline
\end{tabular}

tal stage and the habitat proportions needed by a brown trout population with a balanced age structure. The population structure observed in the segments without physical habitat alterations (sites 2, 7, 8 and 12) was considered to be the balanced or "ideal" population structure. Electrofishing data from these sites were pooled, and the linear regression between age class density and age was computed. The slope of this regression (mortality) was used to derive the habitat distribution of a balanced population structure after a correction for the relative amount of habitat needed by each life stage as given by Bovee (1982): adult habitat area/fry habitat area $=1 / 0.3$; adult habitat area/juvenile habitat area $=1 / 0.8$.

We have selected restoration measures with the purpose of increasing the availability of brown trout habitat. Using the stream classification by Rosgen (1994), all the segments corresponded to class $\mathrm{G}$ (Gc stream type, as the river slope is lower than $2 \%$ ). The $\mathrm{G}$ stream type is characterised by an entrenched channel, low width/depth ratio and moderate sinuosity. Based on this stream classification, we proposed to implement restoration measures that would convert the current $\mathrm{G}$ stream type to a $\mathrm{C}$ type, as proposed by Rosgen (1997) for the restoration of incised rivers. The $\mathrm{C}$ stream type is characterised by a low gradient $(<2 \%)$, a meandering channel, low entrenchment, and riffle-pool morphology.

To implement this restoration, land use should be distanced from the river, thus opening a buffer that would allow the river to develop its natural processes (González del Tánago \& García de 
Jalón, 2007). The streambank walls should be excavated, thereby widening the river channel, and the material should be used to raise the bed elevation. This would reduce the bank height and erosion rate by decreasing the stress near the banks (Rosgen, 1996), thus reducing the sediment input into the channel. In the rectified reaches, a more sinuous channel should be constructed instead of the current straight channel. In general terms, the river channel would become wider and shallower. Afterwards, the river banks should be reforested with indigenous riparian species, and a flow regime as close to natural as possible should be implemented.

A simulation of this restoration action in the Tajuña river was done by means of the MesoHABSIM approach and using the software SimStream 7.1. The restoration was only simulated in altered sites (excluding the unimpaired segments 2, 7, 8 and 12). The simulation has been conducted by the generation of new hydromorphologic models of the restored river segments. The new models were created by changing some attributes of the current models in the way that they would be expected to change if the restoration was implemented, based on the literature and expert opinions, and also considering the relative presence of the attributes in the unimpaired sites. The changes in the hydromorphologic models for the restored scenario were the following (Grant et al., 1990; Rosgen, 1994; 1996; 1997; Palmer et al., 2010). First, the area occupied by runs and glides, which are currently the most abundant HMU types, was reduced and partly replaced by riffles and some rapids, that is, $33 \%$ of the surface occupied by runs and $29 \%$ of the glide area were substituted by riffles ( $85 \%$ of the changed area) and rapids (15\%). Also, the pelal and phytal substrates were reduced $(15 \%$ of pelal and $35 \%$ of phytal points) and were replaced by the substrate types that were beneath the fines and plants in the same proportion that they were observed in the unaltered sites: akal (3\%), microlithal (31\%), mesolithal (38\%) and macrolithal (28\%). Additionally, all the riprap was removed, and submerged vegetation was reduced ( $51 \%$ of HMU surface with this attribute). In the reaches with degraded riparian vegetation, canopy shading (36\% of the mapped area) and overhanging vegetation $(25 \%)$ were increased. Shallow margins were also increased (40 \%), as parts of the river would become wider and shallower.

The depth would decrease in general due to the new channel width, but the implementation of a natural flow regime could potentially compensate for that by providing higher flow during summer, as currently there is a substantial water withdrawal in the summer for irrigation. Because only one type of flow condition has been sampled so far, the depths were not changed in the model. After the application of the attribute changes described above, the model was run again.

To evaluate whether the proposed restoration would provide a significant increase in the amount of available brown trout habitat and which would be the most appropriate segments for restoration, the amount of effective habitat was compared between the current summer conditions and the restored scenario.

Table 3. Biological models generated for brown trout in the Tajuña river. Attributes used by each developmental stage for the variables HMU type, cover type, depth, water velocity and substrate. If the five conditions were satisfied, the HMU was evaluated as optimal habitat. If three conditions (four for the adult) were satisfied, the HMU was evaluated as suitable habitat. Modelos biológicos generados para la trucha común en el río Tajuña. Atributos utilizados por cada estado de desarrollo para las variables tipo de HMU, tipo de cobertura, profundidad, velocidad del agua y sustrato. Si se cumplen las cinco condiciones la HMU se evalúa como hábitat óptimo. Si se cumplen tres condiciones (cuatro para el adulto) la HMU se evalúa como hábitat adecuado.

\begin{tabular}{|c|c|c|c|}
\hline Variable & Adult & Juvenile & Fry \\
\hline HMU type & $\begin{array}{l}\text { Rapids } \\
\text { Riffle } \\
\text { Pool }\end{array}$ & $\begin{array}{l}\text { Rapids } \\
\text { Riffle } \\
\text { Pool }\end{array}$ & $\begin{array}{l}\text { Rapids } \\
\text { Riffle } \\
\text { Side arm } \\
\text { Backwater }\end{array}$ \\
\hline Cover type & $\begin{array}{l}\text { Boulders } \\
\text { Submerged veg. } \\
\text { Undercut }\end{array}$ & Undercut & $\begin{array}{l}\text { Boulders } \\
\text { Shallow margin } \\
\text { Undercut }\end{array}$ \\
\hline Depth & $>50 \mathrm{~cm}$ & $25-100 \mathrm{~cm}$ & $25-75 \mathrm{~cm}$ \\
\hline $\begin{array}{l}\text { Water } \\
\text { velocity }\end{array}$ & $0-45 \mathrm{~cm} \mathrm{~s}^{-1}$ & $0-60 \mathrm{~cm} \mathrm{~s}^{-1}$ & $15-60 \mathrm{~cm} \mathrm{~s}^{-1}$ \\
\hline Substrate & $\begin{array}{l}\text { Pelal } \\
\text { Mesolithal } \\
\text { Megalithal }\end{array}$ & $\begin{array}{l}\text { Mesolithal } \\
\text { Megalithal }\end{array}$ & $\begin{array}{l}\text { Akal } \\
\text { Microlithal } \\
\text { Macrolithal } \\
\text { Megalithal }\end{array}$ \\
\hline
\end{tabular}




\section{RESULTS}

The electrofishing data used for model calibration provided a brown trout total catch ranging from 0 to 100 individuals and trout density varying from 0 to 0.289 individuals $\mathrm{m}^{-2}$. The calibration of the biological models (Table 3 ) yielded significant linear regressions between trout density and the proportion of effective habitat (Fig. 1). The habi-
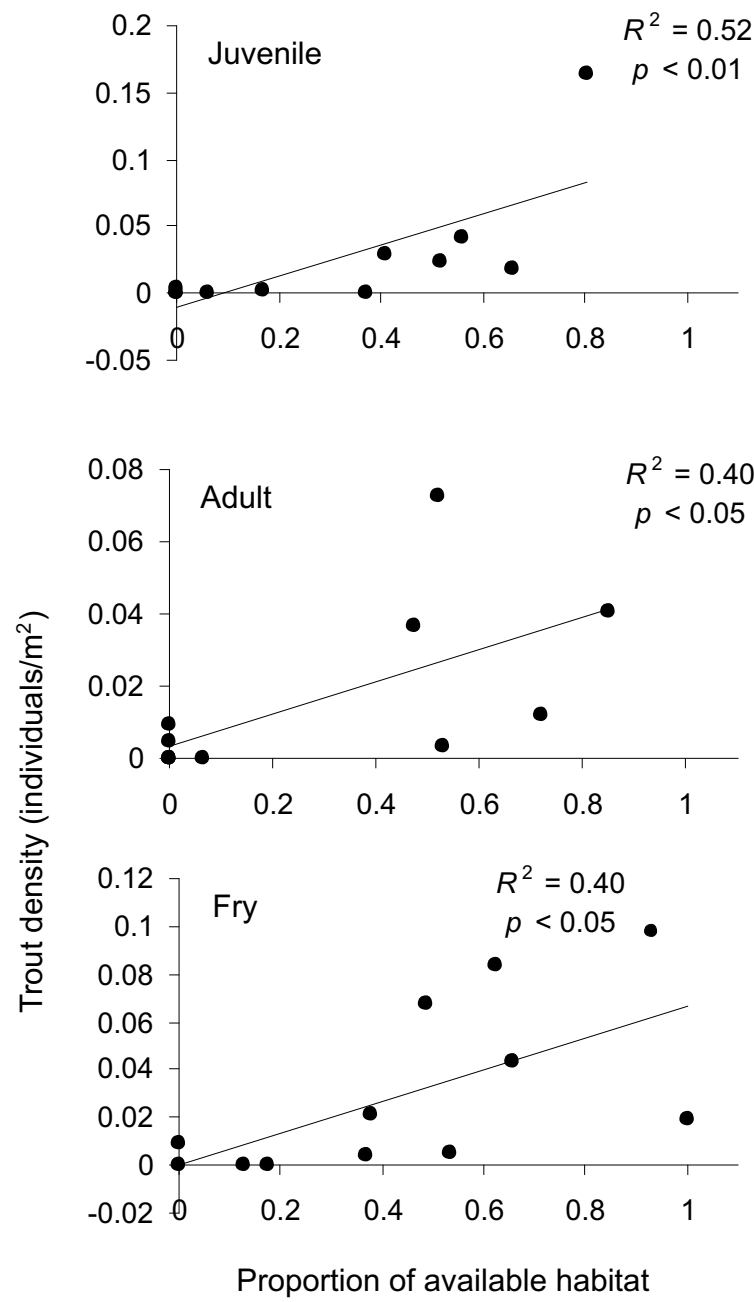

Figure 1. Validation of the biological models for adult, juvenile and fry brown trout. Linear regression analysis between density (individuals $\mathrm{m}^{-2}$ ) and proportion of effective habitat related to the mapped surface within the electrofished area $(n=12)$. Validación de los modelos biológicos para el adulto, juvenil y alevín de trucha común. Regresión lineal entre la densidad (individuos $/ \mathrm{m}^{2}$ ) y la proporción de hábitat efectivo respecto a la superficie muestreada, dentro de la zona en que se realizó pesca eléctrica $(\mathrm{n}=12)$. tat availability obtained by the application of the biological models explained $40 \%$ of the brown trout density for both adults and fry $(p<0.05)$. Juvenile habitat availability explained $52 \%$ of the juvenile trout density $(p<0.01)$.

The application of the biological models in the mapped sites allowed us to quantify the amount of optimal and suitable habitat for each developmental stage at every site (Fig. 2). Optimal habitat was only relevant for adults, while fry and juvenile habitat availability was mainly made up of HMUs that were classified as suitable.

The visual inspection of Table 2 allowed us to identify the main habitat deficits in the current conditions. The most abundant HMU types (glide, run and ruffle) are not adequate for any life stage, while there is a need for more rapids and riffles and for shallow-slow HMU types such as backwaters and side arms. Regarding cover types, Table 2 shows that the increase of undercut banks, boulders and shallow margins would improve habitat suitability. There is an excess of the pelal (which
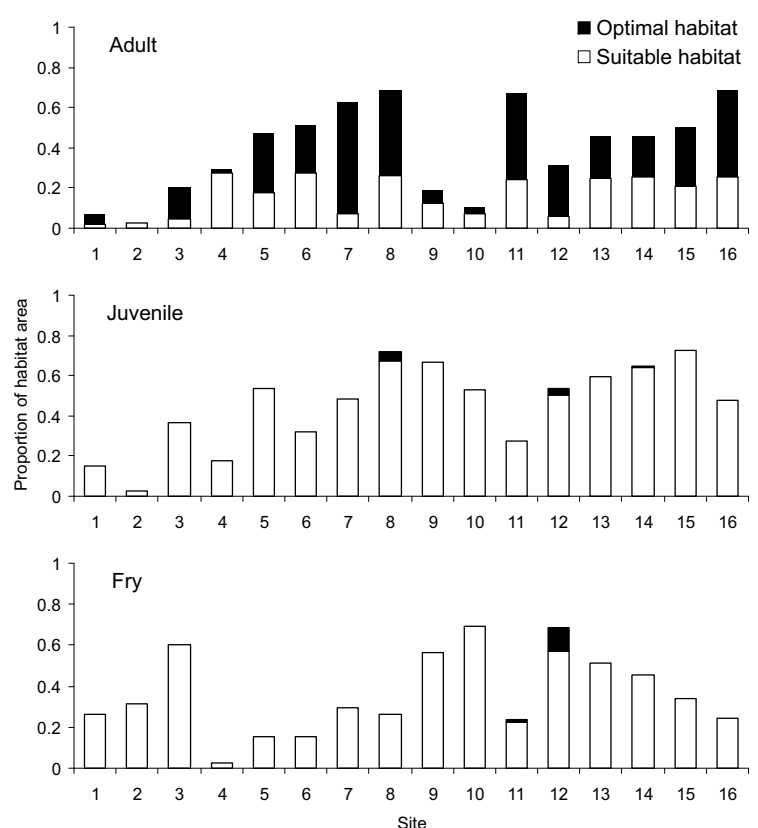

Figure 2. Proportion of suitable (open bars) and optimal (solid bars) habitat area related to the total mapped area in each site for adult, juvenile and fry brown trout. Proporción de la superficie de hábitat adecuado (barras blancas) y óptimo (barras negras) respecto a la superficie total muestreada en cada tramo, para el adulto, juvenil y alevín de trucha común. 


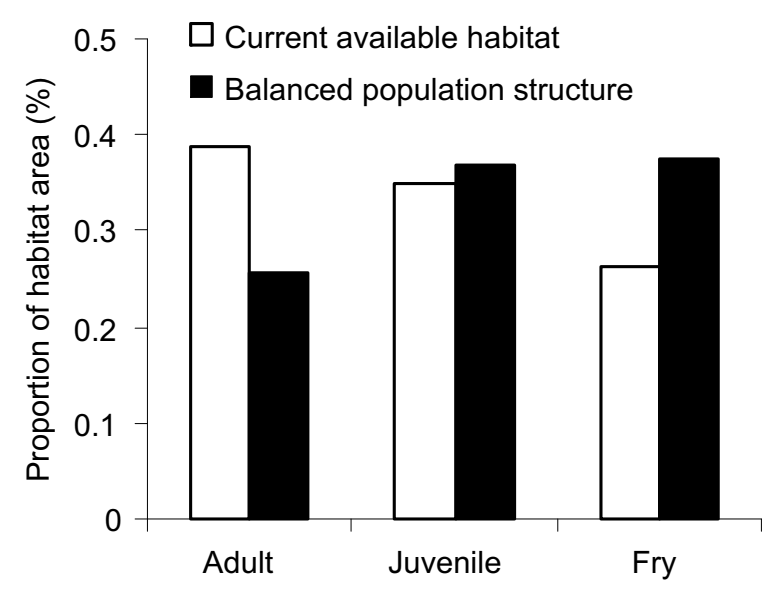

Figure 3. Comparison for the whole study area between the proportion of available habitat for each developmental stage in the current conditions (open bars) and the habitat needed to sustain a balanced population structure (solid bars). Comparación para todo el ámbito de estudio, entre la proporción de hábitat disponible para cada estado de desarrollo en las condiciones actuales (barras blancas) y el hábitat necesario para mantener una población de trucha con una estructura equilibrada (barras negras).

is acceptable for adults, but not for juveniles and fry) and phytal substrates, but there is little akal, macrolithal and megalithal available. The augmentation of these attributes would lead to an increase in habitat availability for brown trout.

Figure 3 shows that fry habitat seemed to be the limiting factor for the development of a balanced population structure in the Tajuña river, as a balanced or "ideal" population requires more fry habitat than is currently available. Therefore, for the design of the restoration measures, we focussed on the habitat needs of brown trout fry.

The results of habitat availability in the restored scenario were compared with the current conditions. The effective habitat (Fig. 4) increased after restoration in almost all instances, except for the adult habitat in some cases (sites 1, 5, 6 and 11). However, the increases were substantial only at sites 1,4 and 16 . At site 1 , the large increase in juvenile and especially fry habitat compensated for the slight reduction in adult habitat. Site 4 also showed a great increase in habitat availability, which was dramatic for fry habitat. At site 16, the largest increase was in juvenile habitat availability.

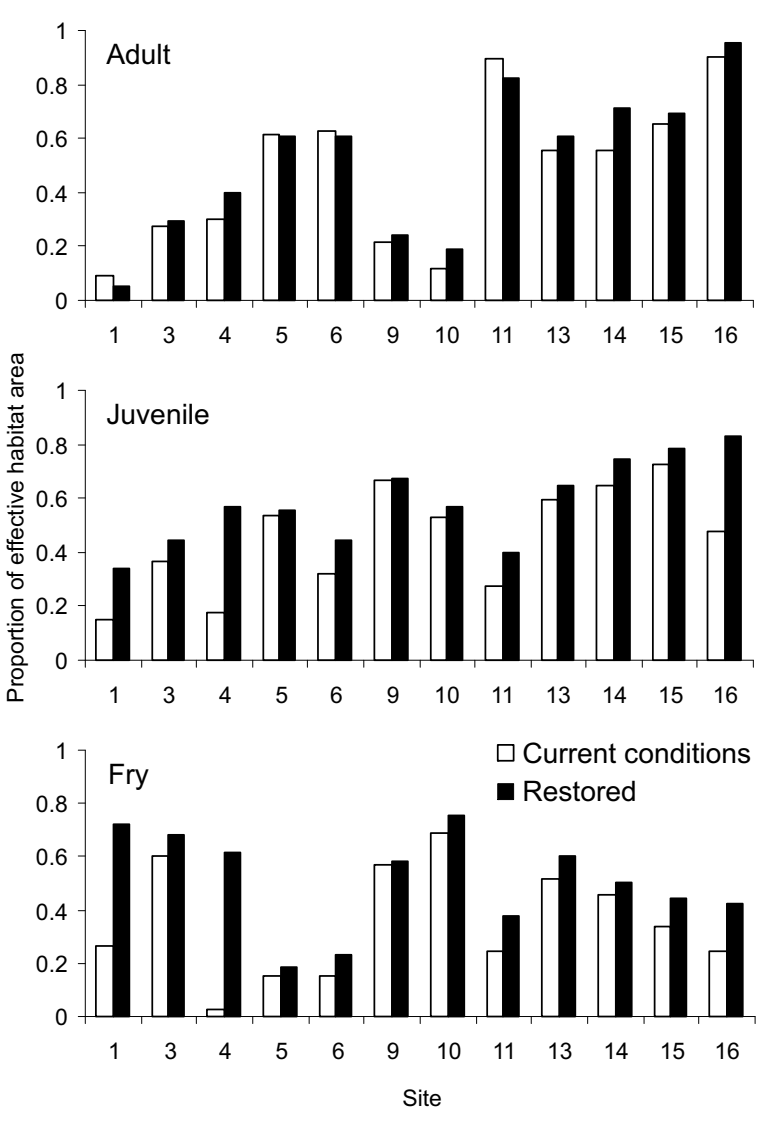

Figure 4. Effective habitat for each developmental stage in the current conditions (open bars) and after restoration (solid bars). Proportion of effective habitat area related to the total mapped area in each site. Hábitat efectivo para cada estado de desarrollo en las condiciones actuales (barras blancas) y tras la restauración (barras negras). Proporción de superficie de hábitat efectivo respecto a la superficie total muestreada en cada tramo.

\section{DISCUSSION}

We showed how physical habitat can be assessed using the MesoHABSIM approach, and we have developed a model of the river that allows us to quantify the available habitat for brown trout when using a single flow value. After this process, the habitat model can be used for a variety of purposes, including the identification of fish habitat deficits, river restoration planning or environmental impact assessment. As a demonstration of the possibilities of MesoHABSIM, we have evaluated how available trout habitat would 
change if a specific restoration action was implemented in the Tajuña river.

The quantification of effective habitat before and after restoration (Fig. 4) allows natural resources managers to evaluate the consequences of restoration on habitat availability for each life stage of brown trout. This information permits evaluating at which sites the proposed restoration measures are worth implementing, depending on the management objectives. For instance, if the goal is to increase the carrying capacity for brown trout and thus to improve population abundance, then we can recommend restoration of sites 1,4 and 16 because it has been estimated that they will experience an important physical habitat improvement. The recommendation of restoration at these three sites focuses on the improvement of fry habitat because it is currently the limiting life stage for the development of a balanced brown trout population. Thus, it is plausible that the whole population would increase after restoration even if the adult habitat slightly decreases in some places, as is the case of site 1. Furthermore, the augmentation of fry habitat availability may have a positive effect on population abundance, as it has been shown that high recruitment induces numerically strong year-classes (Lobón-Cerviá, 2005; 2009). The three sites recommended for restoration (1, 4 and 16) currently show serious alterations such as channel rectification, entrenchment and the degradation of riparian vegetation, so our field observations are congruent with the simulation results.

Regarding the approach used in this work, the use of the mesohabitat scale may involve a loss of accuracy because the meso-scale uses larger scale variables and classes for some variables (e.g., depth and water velocity) instead of the continuous variables used by other models. However, in broad-scale studies, the presumed accuracy loss is overcome by the use of habitat units that are more consistent with the scale of the study (Parasiewicz, 2007). If the mesohabitat scale sacrifices some detail, however, it can reveal larger spatial and temporal ecological patterns that represent system properties (Jewitt et al., 2001). Furthermore, MesoHABSIM is able to quickly collect detailed information about physical conditions from long river reaches (Parasiewicz, 2007), and thus, it can be effectively applied in large-scale projects with reasonable effort. It can easily simulate large scale management actions, allowing for the prediction of effects of measures such as dam removals or extensive channel restoration.

The simulation of a restoration scenario by modifying a physical habitat model, based on existing knowledge of fluvial processes, has been done before by García de Jalón \& Gortázar (2007) using the microhabitat model River2D (Steffler, 2000). In this kind of work, it is important to include enough precision when estimating how habitat attributes will change after restoration to obtain reliable results from the simulation. One good possibility is to create a reference image of the river in natural conditions if the restoration is designed to move the system to its natural state.

In our case, it was not possible to create a reference image of the river in natural conditions because there is a lack of historical information about the river habitat, and the observed geomorphological alterations originated long before the oldest aerial photographs were taken. Moreover, physical habitat in the four unaltered segments cannot be used as reference for the rest of the segments because the two groups of segments do not share the same characteristics in natural conditions. The main difference is in the valley type: the four natural segments are in narrow valleys, and their course is constrained by the hill slopes; the rest of the segments flow through wider valleys, where sinuosity in natural conditions may be greater. For this reason, we have estimated how habitat attributes would change in the restored scenario based on existing knowledge, as explained above.

To obtain reliable results from physical habitat models, another key issue is the capacity of the biological models to reflect actual habitat use by fish in the specific study sites. The biological models attained provide the best possible explanation of trout density by habitat availability in this particular case study. The biological models generated in this work should not be called "preference" models (or "category III" models, 
Bovee, 1986). Rather, they are "use" models because they reflect the fish's use of a range of habitats that include unpaired and altered habitats.

The range of depth used by fish, according to the Tajuña model, is congruent with the category I curves by Bovee (1978) for the three life stages, as the Tajuña depth range always includes the depths with maximum probability in the Bovee model (Fig. 5). The discrepancy is higher with the category I curves given by Raleigh et al. (1986), especially for the adult, as our model uses any depth higher than $50 \mathrm{~cm}$, while Raleigh employs a low probability of use $(<0.4)$ for depths higher than $120 \mathrm{~cm}$.

The range of water velocity used by adults in our model includes all the values that have a probability higher than 0.5 in the Bovee model. Tajuña velocity use by juveniles includes values up to $60 \mathrm{~cm} / \mathrm{s}$, while both the Bovee and Raleigh probability of use is decreasing quickly at this point, reaching approximately 0.3 at $60 \mathrm{~cm} / \mathrm{s}$. In our model, fry do not use velocities lower than $15 \mathrm{~cm} / \mathrm{s}$. This is congruent with the Raleigh model, which gives low suitability for low velocities, but not with Bovee model, which reports maximum probability for velocity lower than approximately $30 \mathrm{~cm} / \mathrm{s}$. The disuse of low water velocity by fry in the Tajuña model may be partly caused by the competition with bigger trout in those microhabitats, displacing fry to other places with higher current and thus higher energetic cost.

In the Tajuña model, fry use the akal (mean diameter between 2-20 $\mathrm{mm}$ ) and microlithal $(20-63 \mathrm{~mm})$ substrate classes, and juveniles and adults use the mesolithal $(63-200 \mathrm{~mm})$. This result is congruent with both the Raleigh and Bovee models, which give high probability $(>0.8)$ for gravel $(2-64 \mathrm{~mm})$ use by fry and for cobble/rubble $(64-250 \mathrm{~mm})$ use by juveniles and adults. Use of the pelal (silt, clay) class by adults in our model also agrees with the Raleigh model (a probability of 1 for silt). The greatest discrepancies in substrate use between the three models are the following: (1) in our model, the megalithal $(>400 \mathrm{~mm})$ class is used by the three life stages, and fry also use macrolithal (200-400 mm), while both the Raleigh and Bovee models show low probability of use $(<0.2)$ for boulders (250-4,000 mm); and (2) Raleigh and Bovee report gravel use by juveniles and sand

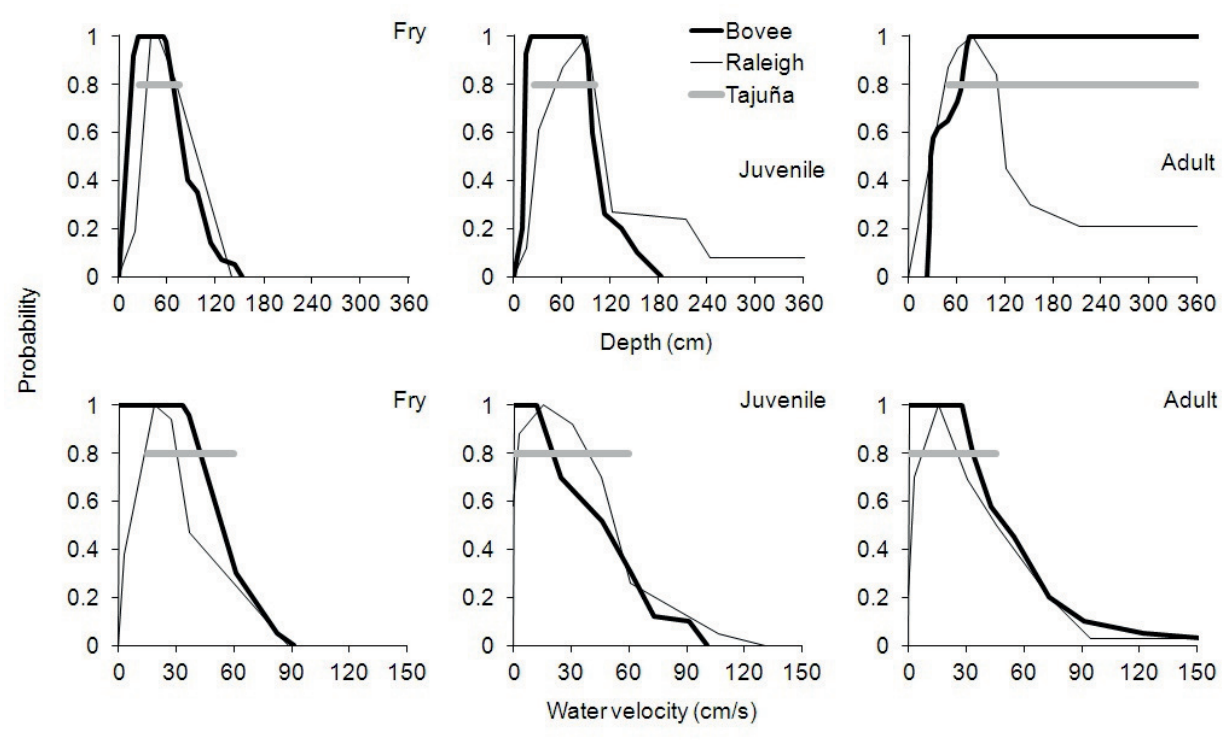

Figure 5. Comparison for the variables depth and water velocity between the biological model of the Tajuña river (grey horizontal bar) and two category I models, reported by Bovee (1978, thick black line) and Raleigh et al. (1986, thin black line). Comparación, para las variables profundidad y velocidad del agua, entre el modelo biológico del río Tajuña (barra horizontal gris) y dos modelos de categoría I publicados por Bovee (1978, línea negra gruesa) y Raleigh et al. (1986, línea negra delgada). 
use by adults and fry, while our model does not consider use in these instances. These differences can be related to habitat availability in the study sites and to a secondary relevance of substrate in the microhabitat selection because other fish habitat studies in Mediterranean rivers (included Tajuña) have reported that depth and velocity are more important (Martínez-Capel et al., 2009). The use of univariate models is also a limitation that can be overcome within the MesoHABSIM approach using multivariate models of mesohabitat variables developed for brown trout in Mediterranean rivers (Mouton et al., 2011).

Regarding HMU type, our model indicates that rapids and riffles are used by the three developmental stages, which reflects the suitability of these HMU types for brown trout (MakiPetays et al., 1997; Roussel \& Bardonnet, 1997). This usage may be partly caused by the scarcity of rapids and riffles in the Tajuña river, which are actively used where present, reflecting the importance of instream habitat heterogeneity (Roussel $\&$ Bardonnet, 2002). Pools are used by juveniles and adults, reflecting the suitability of deep areas for large trout (Modde et al., 1991; Riley \& Fausch, 1995; Roussel \& Bardonnet, 1997). In contrast, fry prefer backwaters and side arms, which are shallow and slow-flowing areas where they can avoid competition with larger trout. This observation is congruent with the findings of Maki-Petays et al. (2000), who showed that fry prefer low-velocity refuges.

Cover is an important element of instream habitat and has been shown to be related to habitat use by trout (Binns \& Eiserman, 1979; Heggenes, 1988a). In the Tajuña model, the three life stages are favoured by the presence of undercut banks, which seems reasonable because this type of cover provides good shelter for brown trout (García de Jalón \& Schmidt, 1995). Fry and adults use the boulder cover type, which provides for interstitial space and low water velocity microniches (Heggenes, 1988b; Heggenes et al., 1993; Bardonnet \& Heland, 1994). Fry also use HMUs with shallow margins, reflecting the needs of small trout for shallow and slow-flowing areas.

Therefore, the biological models used in this work are realistic, as trout chose habitat features that are reasonable in light of the existing knowledge. Furthermore, the biological models have been calibrated with abundance data collected in the field, including both altered and unpaired habitats, and thus, they maximise the relationship between habitat availability and brown trout density in this particular case study.

In this work, we have applied the underlying concepts of MesoHABSIM and its fundamental methods. We have shown how this approach can be used to simulate the effects of restoration measures on instream habitat before the restoration is implemented. This information allows water managers to evaluate whether the restoration measures would be effective and to choose the appropriate sites to implement them. The MesoHABSIM approach permits the simulation of diverse changes in physical habitat, such as river alterations or restoration measures, at the catchment scale, and therefore, it is an efficient tool for decision making in the management of rivers and watersheds.

\section{ACKNOWLEDGEMENTS}

This work was funded by the Regional Government of Castilla-La Mancha, Spain (Junta de Comunidades de Castilla-La Mancha), within the framework of the project "Hydrobiological study of the Tajuña river in the province of Guadalajara" (Estudio Hidrobiológico del río Tajuña en la provincia de Guadalajara). We kindly acknowledge two anonymous reviewers for their important comments and suggestions, which helped us to significantly improve the manuscript. We also thank Joe Rogers (Rushing Rivers) for his helpful advice on the use of Sim-Stream (www.sim-stream.com) software, database management and many other matters throughout the process and David Hernández López for his excellent fieldwork and comments.

\section{REFERENCES}

ARMOUR, C. L., R. J. FISHER \& J. W. TERRELL. 1984. Comparison of the use of the Habitat Eval- 
uation Procedures (HEP) and the Instream Flow Incremental Methodology (IFIM) in aquatic analyses. U.S. Fish and Wildlife Service, FWS/OBS84/11. 30 pp.

ARMSTRONG, J. D., P. S. KEMP, G. J. A. KENNEDY, M. LADLE \& N. J. MILNER. 2003. Habitat requirements of Atlantic salmon and brown trout in rivers and streams. Fisheries Research, 62: 143-170.

BAIN, M. B., J. T. FINN \& H. E. BOOKE. 1985. A quantitative method for sampling riverine microhabitats by electrofishing. North American Journal of Fisheries Management, 5: 489-493.

BARDONNET, A. \& M. HELAND. 1994. The influence of potential predators on the habitat preferenda of emerging brown trout. Journal of Fish Biology, 45(Suppl. A): 131-142.

BINNS, N. A. \& F. M. EISERMAN. 1979. Quantification of fluvial trout habitat in Wyoming. Transactions of the American Fisheries Society, 108: 215-228.

BOVEE, K. D. 1978. Probability-of-use criteria for the family Salmonidae. Instream Flow Information Paper 4. USDI Fish and Wildlife Service. Washington. $80 \mathrm{pp}$.

BOVEE, K. D. 1982. A guide to stream habitat analysis using the instream flow incremental methodology. Instream Flow Information Paper 12. USDI Fish and Wildlife Service. Washington. 248 pp.

BOVEE, K. D. 1986. Development and evaluation of habitat suitability criteria for use in the Instream Flow Incremental Methodology. Instream Flow Information Paper 21. US Fish Wildl. Serv. Biol. Rep. 86(7). 235 pp.

CARLE, F. L. \& M. R. STRUB. 1978. A new method for estimating population size from removal data. Biometrics, 34: 621-380.

GARCÍA DE JALÓN, D. \& J. GORTÁZAR. 2007. Evaluation of instream habitat enhancement options using fish habitat simulations: case-studies in the river Pas (Spain). Aquatic Ecology, 41: 461474.

GARCÍA DE JALÓN, D. \& G. SCHMIDT. 1995. Manual práctico para la gestión sostenible de la pesca fluvial. Madrid: AEMS. ICONA. 169 pp.

GINOT, V. 1995. EVHA, un logiciel d'evaluation de l'habitat du poisson sous Windows. Bull. Fr. Peche Pisc., 337/338/339: 303-308.

GONZÁLEZ DEL TÁNAGO, M. \& D. GARCÍA DE JALÓN. 2007. Restauración de ríos. Guía metodo- lógica para la elaboración de proyectos. Madrid: Ministerio de Medio Ambiente. 318 pp.

GRANT, G. E., F. J. SWANSON \& M. G. WOLMAN. 1990. Pattern and origin of stepped-bed morphology in high-gradient streams, Western Cascades, Oregon. Geol. Soc. Am. Bull., 102: 340-352.

HARDY, T. B. \& R. C. ADDLEY. 2001. Vertical integration of spatial and hydraulic data for improved habitat modelling using geographic information systems. In: Hydroecology: Linking hydrology and aquatic ecology. Proceedings of the Birmingham, United Kingdom Workshop, July 1999. M.C. Acreman (ed.): 65-75. IAHS Publication No. 266. Birmingham, UK.

HEGGENES, J. 1988a. Effect of experimentally increased intraspecific competition on sedentary adult brown trout (Salmo trutta) movement and stream habitat choice. Canadian Journal of Fisheries and Aquatic Sciences, 45: 1163-1172.

HEGGENES, J. 1988b. Substrate preferences of brown trout fry (Salmo trutta) in artificial stream channels. Canadian Journal of Fisheries and Aquatic Sciences, 45: 1801-1806.

HEGGENES, J. 1990. Habitat utilization and preferences in brown trout (Salmo trutta) and juvenile Atlantic salmon (Salmo salar) in streams. PhD Thesis. Agricultural University of Norway, University of Oslo. $319 \mathrm{pp}$.

HEGGENES, J., O. M. W. KROG, O. R. LINDAS, J. G. DOKK \& T. BREMNES. 1993. Homeostatic behavioural responses in a changing environment: brown trout (Salmo trutta) become nocturnal during winter. Journal of Animal Ecology, 62: 295308.

JENS, G. 1968. Tauchstäbe zur Messung der Strömungsgeschwindigkeit und des Abflusses. Deutsche Gewässerkundliche Mitteilungen, 12 (Jahrgang 4): 90-95.

JEWITT, G. P. W., D. C. WEEKS, G. L. HERITAGE \& A. H. M. GORGENS. 2001. Modelling abiotic-biotic links in the rivers of the Kruger National Park, Mpumulanga, South Africa. In: Hydro-ecology: Linking Hydrology and Aquatic Ecology. M.C. Acreman (ed.): 77-90 Proc. Birmingham, UK, Workshop, July 1999, IAHS.

JOWETT, I. G. 1989. River hydraulic and habitat simulation, RHYHABSIM computer manual. New Zealand Fisheries Miscellaneous Report 49. Ministry of Agriculture and Fisheries NZ. Christchurch. 39 pp. 
KEMP, J. L., D. M. HARPER \& G. A. CROSA. 1999. Use of 'functional habitats' to link ecology with morphology and hydrology in river rehabilitation. Aquatic Conservation: Marine and Freshwater Ecosystem, 9(1): 159-178.

LOBÓN-CERVIÁ, J. 2005. The importance of recruitment for the production dynamics of streamdwelling brown trout (Salmo trutta). Canadian Journal of Fisheries and Aquatic Sciences, 62: 2484-2493.

LOBÓN-CERVIÁ, J. 2009. Why, when and how do fish populations decline, collapse and recover? The example of brown trout (Salmo trutta) in Rio Chaballos (northwestern Spain). Freshwater Biology, 54: 1149-1162.

MAKI-PETAYS, A., T. MUOTKA, A. HUUSKO, P. TIKKANEN \& P. KREIVI. 1997. Seasonal changes in habitat use and preference by juvenile brown trout, Salmo trutta, in a northern boreal river. Canadian Journal of Fisheries and Aquatic Sciences, 54: 520-530.

MAKI-PETAYS, A., T. VEHANEN \& T. MUOTKA. 2000. Microhabitat use by age- 0 brown trout and grayling: Seasonal responses to streambed restoration under different flows. Transactions of the American Fisheries Society, 129(3): 771-781.

MARTÍNEZ-CAPEL, F., D. GARCÍA DE JALON, D. WERENITZKY, D. BAEZA \& M. RODILLAALAMÁ. 2009. Microhabitat use by three endemic Iberian cyprinids in Mediterranean rivers (Tagus River Basin, Spain). Fisheries Management and Ecology, 16(1): 52-60.

MOUTON, A. M., J. D. ALCARAZ-HERNÁNDEZ, B. DE BAETS, P. L. M. GOETHALS, F. MARTÍNEZ-CAPEL. 2011. Data-driven fuzzy habitat suitability models for brown trout in Spanish Mediterranean rivers. Environmental Modelling \& Software 26: 615-622.

MODDE, T., R. C. FORD, \& M. G. PARSONS. 1991. Use of a Habitat-Based Stream Classification System for Categorizing Trout Biomass. North American Journal of Fisheries Management, 11: 305311.

PALMER, M. A., H. L. MENNINGER \& E. BERNHARDT. 2010. River restoration, habitat heterogeneity and biodiversity: a failure of theory or practice? Freshwater Biology, 55 (Suppl. 1): 205-222.

PARASIEWICZ, P. 2007. The MesoHABSIM model revisited. River Research and Applications, 23(8): 893-903.

PARASIEWICZ, P. \& M. J. DUNBAR. 2001. Physical habitat modelling for fish-a developing approach. Large Rivers, 12(2-4): 239-268.

PARASIEWICZ, P., J. GORTÁZAR, M. MATEO \& D. GARCÍA DE JALÓN. 2009. MesoHABSIM: una herramienta eficaz para la gestión de ríos y cuencas fluviales. Tecnología del Agua, 309: 2026.

RALEIGH, R. F., L. D. ZUCKERMAN \& P. C. NELSON. 1986. Habitat suitability index models and instream flow suitability curves: brown trout. Biological Report 82. USDI Fish and Wildlife Service.

RILEY, S. C. \& K. D. FAUSCH. 1995. Trout population response to habitat enhancement in six northern Colorado streams. Canadian Journal of Fisheries and Aquatic Sciences, 52: 34-53.

ROSGEN, D. L. 1994. A classification of natural rivers. Catena, 22: 169-199.

ROSGEN, D. L. 1996. Applied River Morphology. Pagosa Springs: Wildland Hydrology Books. 364 pp.

ROSGEN, D. L. 1997. A geomorphological approach to restoration of incised rivers. In: Proceedings of the Conference on Management of Landscapes Disturbed by Channel Incision. S. S. Y. Wang, E. J. Langendoen \& F. D. Shields, Jr. (eds.): 12-22. Oxford. University of Mississippi. USA.

ROUSSEL, J. M. \& A. BARDONNET. 1997. Diel and seasonal patterns of habitat use by fish in a natural salmonid brook: An approach to the functional role of the riffle-pool sequence. Bulletin Français de la Pêche et de la Pisciculture, 346: 573-588.

ROUSSEL, J. M. \& A. BARDONNET. 2002. The habitat of juvenile brown trout (Salmo trutta L.) in small streams: Preferences, movements, diel and seasonal variations. Bulletin Français de la Pêche et de la Pisciculture, 365-366: 435-454.

STEFFLER, P. 2000. Software River2D. Two Dimensional Depth Averaged Finite Element Hydrodynamic Model. University of Alberta, Canada. 
